\title{
Social Media Marketing, Electronic Word of Mouth, and its Effect on Purchase Decision Process on The Warunk Upnormal Consumer
}

\author{
Farah Oktafani, Nadya Novandriani K.M., Marheni Eka Saputri, Trisha Gilang \\ Saraswati \\ Telkom University \\ E-mail address Farahokt@telkomuniversity.ac.id
}

\begin{abstract}
There Warunk UpNormal uses a variety of promotional strategies, including through social media. Warung UpNormal target market is the millennial segment, which is the largest segment in Indonesia's current demographic structure. Therefore, through social media, Warunk UpNormal establishes intense marketing communication with its target market. The purpose of this paper is to examine the effects of social media marketing and electronic word of mouth on a purchase decision process in Warunk UpNormal. A quantitative research methodology was used for the purpose of this research, and the data were collected from 400 customers of Warunk UpNormal who have seen social media and read reviews provided by Warunk Upnormal. The study finds that customers responded positively to Warunk UpNormal social media content, and they have engagement with Warunk UpNormal through social media. Contrary to expectation, the findings showed that both social media marketing and electronic word of mouth has positives but insignificant effect on the purchase decision process. The finding of this study contributes to an understanding of the selected factors in affecting the customer decision process in Warunk UpNormal.
\end{abstract}

Keywords: Electronic Word of Mouth, Social Media Marketing, Purchase Decision Process.

\section{INTRODUCTION}

This is an open access article under the CC-BY-NC license.

The culinary industry is growing rapidly in Indonesia, characterized by the growth of many new players, especially those from MSMEs. According to the ministry of industry's data, culinary industry growth in Indonesia reached $9.23 \%$ in 2017 , up from $8.46 \%$ in 2016 . In addition, the food franchise will be increasingly squirming in the midst of culinary hobbies that hit urban communities in 2019. The success of the culinary BusinessBusiness is seen from data that as many as 60 million SMEs in the country, food, and beverage products are the most contributing. Its contribution is above 60 percent or about 40 million MSME actors (www.medcom.id).).

Technological developments have had such a large impact in various fields of BusinessBusiness, including advertising and marketing. The internet has become an important part for companies to market their products. Especially because of the development of internet users and has become part of today's lifestyle. one of the fastest-growing internet products is social media. 
Initially, social media was used as a gathering medium before then rapidly developed as a modern marketing tool.

Warung Upnormal is one of Bandung's original culinary brands that are very popular among teenagers and young adults. Warung Upnormal was founded in 2014 and became very popular because it is the first modern stall to modernize the concept of instant noodle shops. Warung Upnormal's target market is the millennial segment, which is the largest segment in Indonesia's demographic structure today. Social media is the place to be when it comes to engaging and marketing to millennials. Most internet users in Indonesia are those who access social media, especially among millennials. According to the 2017 Tetra Pak Index (www.inet.detik.com), there are around 132 million internet users in Indonesia. At the same time, almost half are social media enthusiasts or around $40 \%$. This figure increased compared to last year; in 2016, the increase of internet users in Indonesia was around $51 \%$ or around 45 million users, followed by a growth of $34 \%$ active users of social media. While users who access social media through mobile are $39 \%$. from these data, it can be concluded that social media in Indonesia is very attractive to the public, including promotional content. The use of marketing strategies called social media marketing is one way to do promotion to increase sales of a business. Tom Funk (2011) mentioned useful Social Media gives individuals the ability to set personal profits, connect with other users, create, publish, and respond to content. According to Kotler \& Armstrong (2012), Social Media, too as an online community tool where people are connected in a particular community. This Social Media Network is a new form of a dialogue between "consumer-to-consumer" and "business-to-consumer," which has major implications for marketers. Promotional activities can also be done by sharing reviews; this activity causes the activity of spreading information by word of mouth. In addition to sharing information through word of mouth directly, this activity can also be done through electronic media (electronic word of mouth) online. This activity can automatically help consumers to share experiences about the products and services obtained.

\section{LITERATURE REVIEW}

Electronic word of mouth (eWOM) can be interpreted as a form of consumer willingness to voluntarily provide recommendations to others to provide or describe products from a company through the internet (Syarifuddin et al. 2016). Social media uses many policies in linking information collaboratively so that the information conveyed can be well received by those who receive information. In social media, there are social networking sites that are often used as promotional media. Social networking is a site where anyone can create a personal web, then connect with friends to share information and communicate. The biggest social networks today are Instagram, Facebook, and Twitter. Social media invites anyone who is interested in participating by contributing and feedback openly, giving comments, and sharing information in fast and unlimited time. Gunelius (2011) wrote that dimensions of Social Media Marketing used in this study consisted of content creation, content sharing, connecting, and community building.

Electronic word of mouth has now developed rapidly in the form of review sites where customers can share experiences and exchange information about products and services. Research conducted by S.J. Bae et al. (2016) states that there are effects caused by eWOM, namely the market and individuals. The impact of eWOM on the market is how to share experiences together that affect individuals adopting information by reading reviews and how tourists shape their purchase intentions after traveling. At the same time, the impact of eWOM on individuals focusing on product sales and analyzing how individuals are affected by the eWOM effect personally. Dissemination of information through Electronic Word of Mouth (eWOM) is done through online media, with the existence of online social communication that can automatically help consumers to share experiences 
about products or services that they obtain during the purchase process. Goyette (2010) divides the electronic word of mouth into three dimensions, namely:

1. Intensity

2. Valance of Opinion

3. Content

Sudaryono (2014) mentioned The process of decision making begins with the need to try to be fulfilled. In meeting this need associated with several alternatives, it is necessary to conduct an evaluation that aims to obtain the best alternative from consumer perceptions. According to Kotler \& Keller (2012), the purchase decision process consists of five stages: problem recognition, information search, alternative assessment, the decision to buy, and post-purchase behavior.

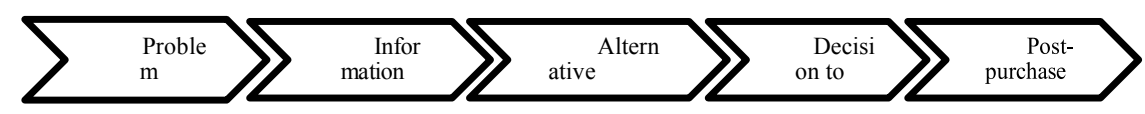

Figure 1.Purchase Decision Process (Source: Kotler and Keller, 2012)

Based on the problems previously mentioned, this study aims to know the effect of (1) Social Media Marketing to Purchase Decision Process, (2) Electronic Word Of Mouth to Purchase Decision Process, and ; (3) Social Media Marketing and Electronic Word Of Mouth to Purchase Decision Process.

\section{RESEARCH METHODOLOGY}

The data were collected through observation, interviews, and questionnaires. The population in this study is Warunk Upnormal Consumers are social media followers whose numbers are not known with certainty. The sampling technique used in this study was purposive sampling. The sample criteria used are individuals who have seen social media and read the reviews provided by Warunk Upnormal. The samples taken for this study were 400 people. This study uses descriptive analysis to describe the state of the dependent and independent variables - multiple linear regression used as a technique of data analysis. F and t-tests are used to determine the effect simultaneously and partially between dependent and independent variables. While The coefficient of determination is used to explain how much influence the independent variable has on the dependent variable.

\section{FINDING AND DISCUSSION}

Based on the results of the statistical calculation stipulated earlier, it can be concluded that all the variables studied are in the category of good. Social media marketing can be said to be good due to waroenk normal social media content looks interesting and easy to understand by consumers, so there is effective communication between the company and the consumer. In addition, social media content on Waroenk Upnormal has also helped consumers to be able to know the existing products. Warren Upnormal social media presents many menu images, product information, ongoing promotional information, as well as admins providing feedback on questions or complaints submitted by consumers. 
Electronic word of mouth on Waroenk Upnormal can be said to be good because of the many reviews given by consumers so as to make consumers know about warren normal products. In addition, many reviews also make the reader become more curious and want to try the product. Another advantage of Waroenk Upnormal is that they provided columns or media for consumers to deliver advice or criticism for the company, or consumers can also ask questions.

The purchase decision process on Waroenk Upnormal can be said to be good because the consumer understands his or her needs in choosing a place to eat that suits his or her needs. In search of information about these needs, consumers look for it through social media and read the reviews that are both positive and negative. Reviews on social media influence consumers to choose Waroenk Upnormal, and consumers are satisfied after choosing the product. Most of the consumers stated that they would make a buyback.

The results of multiple regression analysis are $\mathrm{Y}=17.909+0,142 \mathrm{X} 1+0,450 \mathrm{X} 2+\mathrm{e}$. The constant of 17.909 explained that if there is no social media marketing and no electronic word of mouth, the value of the customer purchase process is worth 17.909, assuming the other factors are constant. The coefficient of $\mathrm{X} 1$ is 0.142 , point out that when social media marketing is increasing, it will positively affect the purchase decision process by 0.142 with the assumption the other factors are constant. The coefficient of X2 is 0.405 showed us that every increase of electronic word of mouth would positively affect the purchase decision process by 0.405 , assuming that every other factor is constant. This positive influence shows that the higher the social media marketing and electronic word of mouth of Warunk Upnormal, the higher the purchase decision process.

Warung Upnormal social media content is perceived as attractive and easily understood by customers. Warung Upnormal social media presents a lot of menu images, product information, and ongoing promotion information; the admin provides feedback on questions and complaints submitted by consumers ensuring engagement with them. Although the result of the questionnaire shows that Warunk Upnormal social media marketing is in a good category, the t-test result of social media marketing is only 0.053 , which means that social media marketing partially has a positive influence but insignificant effect on the purchase decision process. The result of consumer perception about electronic word of mouth shows that the number of reviews given by consumers makes other consumers aware and curious about Warung Upnormal products. Furthermore, Warunk Upnornal also provides a column for the customer to give criticism, suggestion, or just to ask questions. This has led to high customer engagement. Even though it is in a good category, the t-test result of electronic word of mouth is 0.031 , which means that e-wom partially has a positive influence but an insignificant effect on the purchase decision process. The F test result is 3.09, which means that social media marketing and e-wom simultaneously have a positive effect on the purchasing decision process on Warunk Upnormal. Coefficient determination (R2) is 0.084 , which means $8,4 \%$ of the purchasing decision process can be explained by social media marketing and e-wom, while the rest of $91,6 \%$ is explained by other variables not included in this study.

\section{CONCLUSION AND FURTHER REASEARCH}

The t-test result of social media marketing is 0.053 , indicates that social media marketing partially has a positive influence but an insignificant effect on the purchase decision process. While the t-test result of electronic word of mouth result is 0.031 , means that electronic word of mouth partially has a positive influence but insignificant effect on the purchase decision process. The F-test result is 3.09, suggesting that social media marketing and electronic word of mouth simultaneously have a positive effect on the purchasing decision process on Warunk Upnormal. Coefficient determination (R2) is 0.084 , which implies that $8,4 \%$ of the purchasing decision process can be explained by social media marketing and electronic word of mouth. Although the results of the study 
show a positive effect, the effect is not significant on the purchase decision process; then, Warung Upnormal should look for other factors that are more influential on the purchase decision process.

\section{REFERENCES}

Funk, Tom. (, 2011). Social Media Playbook for Business: Reaching Your Online Community with Twitter, Facebook, LinkedIn, and More. USA: Praeger Publishers.

Goyettee, Isabelle. (, 2010). e-WOM Scale: word-of-mouth measurement scale for e-services context. Canadian Journal of Administrative Sciences. Canada: John Wiley \& Sons, Ltd.

Gunelius, Susan. (, 2011). 30 minute Social Media Marketing: Step by Step Techniques to Spread the Words about your BusinessBusiness. New York: McGraw-Hill.

Kotler, Phillip \& Keller, Kevin L. 2016. Marketing Management. 16th Edition. New Jersey: Prentice Hall Published.

Kotler, Phillip \& Keller, Kevin L. 2012. Manajemen Pemasaran. Edisi 12. Jakarta: Erlangga. (S.J. Bae et.al. 2016).

Sudaryono. 2014. Perilaku Konsumen Dalam Prespektif Pemasaran. Jakarta: Lentera Ilmu Cendekia. (Syarifuddin et.al. 2016).

https://www.medcom.id/ekonomi/mikro/akWGnXdk-umkm-kuliner-makin-bergeliat-di-2019 